\title{
Aktivitas Antioksidan Formulasi Sediaan Sabun Cair Dari Buah Apel (Malus Domesticus)
}

\section{Antioxidant Activities For Liquid Soap Formulation From Apple Fruit (Malus Domesticus)}

\author{
Rulia Meilina $^{1 *}$, Intan Safitri Japnur ${ }^{2}$, Marniati $^{3}$ \\ ${ }^{1,2}$ Universitas Ubudiyah Indonesia, Banda Aceh and 23114, Indonesia \\ *Koresponding Penulis: ${ }^{1}$ Rulia.meilina@uui.ac.id ; ${ }^{2}$ Intan.japnur@gmail.com, marniati@uui.ac.id ${ }^{3}$
}

\begin{abstract}
Abstrak
Buah apel memiliki senyawa fitokimia yang berfungsi sebagai antioksidan alami dari golongan flavonoid yang sangat bagus untuk kesehatan kulit. Penelitian dilakukan secara eksperimental. Sediaan sabun cair dibuat dengan menambahkan ekstrak apel dengan variasi konsentrasi yaitu 2,5g (F1), 3g (F2) dan 3,5g (F3), sebagai blanko (F0). Pengujian terhadap sediaan sabun cair meliputi pemeriksaan uji organoleptik, pengukuran $\mathrm{pH}$ sediaan, uji ketahanan busa, uji iritasi terhadap kulit, uji kesukaan sediaan (hedonic test), dan uji aktivitas antioksidan. $\mathrm{pH}$ sediaan $(7,9-9,00)$ dan stabilitas busa memenuhi persyaratan nilai SNI, sediaan stabil dalam penyimpanan dan tidak menimbulkan iritasi pada kulit sukarelawan. Ekstrak buah apel merah dapat diformulasikan sebagai sediaan sabun cair dan tidak menyebabkan iritasi. Sediaan sabun cair dengan konsentrasi ekstrak apel 3,5g pada formula 3 (F3) menunjukkan efektivitas sebagai formulasi yang paling baik dan paling disukai oleh sukarelawan.
\end{abstract}

\section{Kata Kunci : Ekstrak buah apel, Sabun cair, antioksidan}

\begin{abstract}
Apples contain phytochemical compounds that contain natural antioxidants which are very good for skin health. The study was conducted experimentally, Liquid bath soap preparations are made by adding apple extract with variations in concentration of $2.5 \mathrm{~g}(\mathrm{~F} 1), 3 \mathrm{~g}$ (F2) and $3.5 \mathrm{~g}$ (F3), as blank (F0). Tests for liquid bath soap preparations include examination of organoleptic tests, measurement of $\mathrm{pH}$ of preparations, foam resistance tests, skin irritation tests, hedonic test, and antioxidant activity tests. The $\mathrm{pH}$ of the preparations (7.9-9.00) and foam stability met the requirements of SNI values, the preparations were stable in storage and not irritating to the skin of volunteers Red apple extract can be formulated as a liquid bath soap preparation and does not cause irritation. Liquid soap with $3.5 \mathrm{~g}$ in formula 3 (F3) apple extract concentration shows effectiveness as the best and most preferred formulation by volunteers.
\end{abstract}

Keywords: Apple extract, Liquid soap, antioxidants. 
Apel (Malus domestica) merupakan tanaman buah tahunan berasal dari Asia Barat yang beriklim sub-tropis. Apel dapat tumbuh di Indonesia setelah tanaman apel ini beradaptasi dengan iklim Indonesia, yaitu iklim tropis (Baskara, 2010). Apel mengandung zat antioksidan alami dari golongan flavonoid yang sangat bagus untuk kesehatan kulit.

Antioksidan merupakan senyawa yang dapat melindungi senyawa lain dari oksidasi oleh radikal bebas. Secara ilmiah, tubuh manusia menghasilkan antioksidan . Namun, seringkali senyawa ini tidak cukup untuk melindungi tubuh sehingga diperlukan asupan antioksidan dari luar tubuh. (Moniharapon, dkk., 2016).

Bentuk sediaan farmasi yang dapat digunakan untuk menjaga kesehatan kulit salah satu diantaranya ialah sabun. Sabun adalah produk yang dihasilkan dari reaksi asam lemak dengan basa kuat yang berfungsi untuk mencuci dan membersihkan lemak (kotoran) (Hernani, dkk., 2010). Terdapat berbagai jenis sabun di masyarakat, seperti sabun cuci, sabun mandi, sabun tangan dan sabun wajah. Selain itu, berdasarkan konsistensinya, dikenal pula adanya sabun krim, sabun padat dan sabun cair.

\section{METODELOGI PENELITIAN}

\section{Alat dan bahan}

Alat-alat yang digunakan dalam penelitian ini adalah Spektrofotometri UV-Vis. Bahanbahan yang digunakan dalam penelitian ini adalah buah apel, Minyak Zaitun, KOH, etanol 96\%, asam stearat, gliserin, CMC, Cocodea, parfum dan aquades.

\section{Pembuatan Ekstrak}

Apel dibersihkan dan dikerimgkan hingga menjadi simplisia, lalu dihaluskan untuk memperoleh serbuk halus. Serbuk apel diekstraksi dengan metode maserasi. Hasil ekstrak cair tersebut dipekatkan dengan rotary evaporator sehingga diperoleh ekstrak kental, kemudian dilakukan pengujian skrining fitokimia. (Meilina, dkk., 2018). 


\section{Formulasi sabun cair}

\begin{tabular}{cccc} 
Nama Zat & F1 & F2 & F3 \\
\hline Estrak apel & $2,5 \mathrm{~g}$ & $3 \mathrm{~g}$ & $3,5 \mathrm{~g}$ \\
Minyak zaitun & $20 \mathrm{~mL}$ & $20 \mathrm{~mL}$ & $20 \mathrm{~mL}$ \\
KOH & $20,3 \mathrm{~mL}$ & $20,3 \mathrm{~mL}$ & $20,3 \mathrm{~mL}$ \\
Gliserin & $13 \%$ & $13 \%$ & $13 \%$ \\
Asam stearat & $7 \mathrm{~g}$ & $7 \mathrm{~g}$ & $7 \mathrm{~g}$ \\
Aquades & $100 \mathrm{~mL}$ & $100 \mathrm{~mL}$ & $100 \mathrm{~mL}$ \\
Cocodea & $5 \%$ & $5 \%$ & $5 \%$ \\
Parfum & Qs & Qs & Qs \\
\hline
\end{tabular}

Tabel 1. Formulasi sabun cair.

Pembuatan sabun cair diawali dengan dipanaskan asam stearat sampai mencair kemudian tambahkan minyak zaitun ke dalam gelas kimia, kemudian ditambahkan dengan kalium hidroksida sedikit demi sedikit terus dipanaskan pada suhu $50^{\circ} \mathrm{c}$ hingga mendapat sabun pasta. Sabun pasta ditambahkan dengan kurang lebih $15 \mathrm{~mL}$ aquades, lalu ditambahkan gliserin yang telah dikembangkan dalam aquades panas, diaduk hingga homogen. Kemudian ditambahkan cocodea (sebagai pembusa) dan diaduk hingga homogen. Dimasukkan ekstrak apel diaduk hingga homogeny, kemudian sabun cair ditambahkan dengan aquades hingga volume $100 \mathrm{~mL}$ dan diaduk hingga homogen. Evaluasi sediaan sabun cair meliputi uji organoleptik, Uji pH, Uji ketahanan busa, Uji iritasi terhadap kulit, Uji Kesukaan, Uji aktivitas antioksidan.

\section{HASIL DAN PEMBAHASAN}

Skrinning Fitokimia

Hasil skrinning fitokimia dapat dilihat pada Tabel 2.

\begin{tabular}{lc}
\hline \multicolumn{1}{c}{ Kandungan metabolit } & Hasil uji \\
\hline Alkaloid & negatif \\
Steroid & negatif \\
Terpenoid & posisif \\
Saponin & negatif \\
Flavanoid & posisif \\
Fenol & posisif \\
Tanin & posisif \\
\hline
\end{tabular}

Tabel 2. Skrining Fitokimia 
Journal of Healthcare Technology and Medicine Vol. 6 No. 1 April 2020

Universitas Ubudiyah Indonesia

e-ISSN : 2615-109X

\section{Hasil Uji Organoleptik}

Dari hasil organoleptik sabun cair menunjukkan bahwa pada ketiga formula tersebut stabil selama penyimpanan dan tidak mengalami perubahan warna, bau, dan tekstur.

\section{Hasil pH Sediaan}

Evaluasi $\mathrm{pH}$ sediaan menunjukkan nilai $\mathrm{pH}$ yang relatif stabil. Hasil dapat dilihat pada

\section{Gambar 1.}

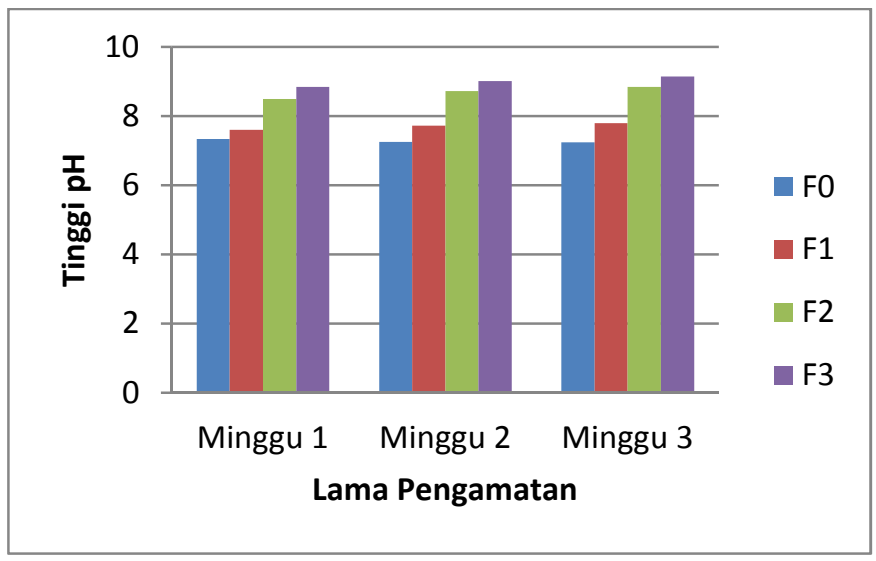

Gambar 1. Grafik pH sediaan

Dari grafik di atas terlihat bahwa selama proses penyimpanan sabun cair mengalami peningkatan $\mathrm{pH}$ pada setiap minggunya, hal ini disebabkan oleh pengaruh suhu ruang dan masa penyimpanan, namun masih pada rentang nilai $\mathrm{pH}$ yang diperbolekan oleh SNI untuk sediaan sabun cair. Kesesuaian $\mathrm{pH}$ kulit dengan $\mathrm{pH}$ sediaan topical mempengaruhi penerimaan kulit terhadap sediaan (Meilina dan Afriana, 2019).

\section{Hasil Uji Stabilitas Busa}

Hasil uji stabilitas busa dilihat pada Tabel 3.

\begin{tabular}{cccc}
\hline Formula & Tinggi awal & Busa akhir & Persentase tingi busa (\%) \\
\hline F0 & $7 \mathrm{~cm}$ & $6,5 \mathrm{~cm}$ & $92,8 \%$ \\
F1 & $6,5 \mathrm{~cm}$ & $5,5 \mathrm{~cm}$ & $84,6 \%$ \\
F2 & $6 \mathrm{~cm}$ & $5,5 \mathrm{~cm}$ & $91,6 \%$ \\
F3 & $7,5 \mathrm{~cm}$ & $7 \mathrm{~cm}$ & $93,3 \%$ \\
\hline
\end{tabular}

Tabel 3. Hasil Uji Busa 
Journal of Healthcare Technology and Medicine Vol. 6 No. 1 April 2020

Universitas Ubudiyah Indonesia

e-ISSN : 2615-109X

Hasil menunjukan bahwa formula 3 (F3) menghasilkan busa lebih tinggi dari formula yang lain karena pada (F3) konsentrasi ekstrak buah apel yang dipakai lebih banyak dibandingkan dengan formula yang lain. Hasil perhitungan stabilitas dari formula 3 (F3) memiliki nilai stabilitas busa sebesar 93,3\%. Pada formula 2 (F2) memiliki nilai stabilitas busa sebesar 91,6\%. Dan formula 1 menghasilkan busa yang paling rendah, tetapi masih dapat dikatakan memiliki stabilitas yang baik karena memiliki nilai diatas $70 \%$, yaitu $84,6 \%$.

\section{Hasil uji iritasi}

Berdasarkan hasil uji iritasi yang dilakukan pada 6 orang panelis yang dilakukan dengan cara mengoleskan sediaan sabun cair ekstrak apel pada kulit belakang telinga selama 12 jam, menunjukkan bahwa semua panelis tidak menunjukkan reaksi terhadap parameter reaksi iritasi yang diamati yaitu adanya edema, eritema, papula, ataupun adanya vesikula. Dari hasil uji iritasi tersebut dapat disimpulkan bahwa sediaan sabun cair yang dibuat aman untuk digunakan.

\section{Hasil uji kesukaan}

Berdasarkan nilai rata-rata kesukaan untuk setiap sediaan, sediaan yang paling disukai adalah sediaan sabun cair dengan konsentrasi ekstrak buah apel 3,5 g dengan jumlah rata-rata 4,5. Hasil dapat dilihat pada Gambar 2.

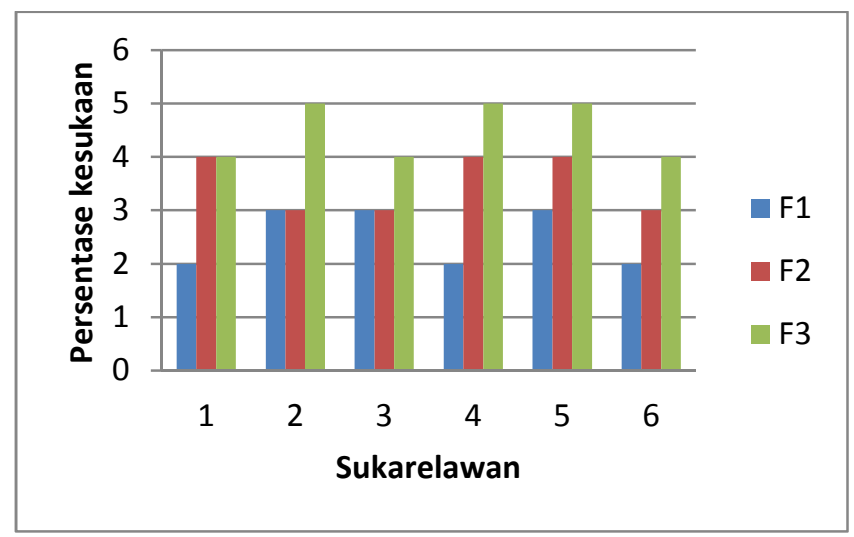

Gambar 2. Hasil uji kesukaan 
Journal of Healthcare Technology and Medicine Vol. 6 No. 1 April 2020

Universitas Ubudiyah Indonesia

e-ISSN : 2615-109X

\section{Hasil Antioksidan}

Hasil penentuan panjang gelombang maksimun larutan DPPH pada panjang gelombang $517 \mathrm{~nm}$ didapatkan nilai absorbansi sebesar 0,623. Panjang gelombang maksimun nilai absorbansi yang didapat digunakan untuk uji antioksidan pada sediaan sabun cair buah apel. Hasil dapat dilihat pada Tabel 4.

\begin{tabular}{rccc}
\hline Sampel & Absorbansi & Blanko & \% Inhibisi antioksidan \\
\hline F0 & 0,342 & 0,623 & 45,10 \\
F1 & 0,423 & 0,623 & 32,10 \\
F2 & 0,409 & 0,623 & 34,35 \\
F3 & 0,372 & 0,623 & 40,29 \\
\hline
\end{tabular}

Tabel. 4 Hasil Antioksidan

Hasil tersebut menunjukan bahwa daya hambat antioksadan sabun cair ekstrak buah apeh paling tinggi yaitu pada formula 3 (F3) sebesar 40,29\% karena pada F3 kiandungan ekstrak apel lebih banyak dibandingkan dengan formula lain, dan paling rendah pada formula 1 (F1) sebesar 32,10\%. Hal ini menunjukkan jumlah ekstrak apel pada setiap formula berpengaruh terhadap nilai aktivitas antioksidan.

\section{KESIMPULAN}

Ekstrak buah apel dapat diformulasikan sebagai sabun cair karena tidak menyebabkan iritasi pada kulit setelah dilakukan pengujian terhadap sukarelawan selama 24 jam. Perbedaan konsentrasi ekstrak buah apel yang diformulasikan dalam sediaan sabun cair memberikan berpengaruh terhadap nilai aktivitas antioksidan.

\section{SARAN}

Disarankan kepada peneliti selanjutnya dapat melakukan uji dermatologi terhadap sabun cair ekstrak apel. 
Journal of Healthcare Technology and Medicine Vol. 6 No. 1 April 2020

Universitas Ubudiyah Indonesia

e-ISSN : 2615-109X

\section{DAFTAR PUSTAKA}

Baskara, M. (2010). Pohon Apel itu masih (bisa) berbuah lebat. Majalah Ilmiah Populer Bakosurtanal Ekspedisi Geografi Indonesia. Jawa Timur.

Hernani, B. T.K., dan Fitriati, (2010), Formula Sabun Transparan Anti jamur Dengan Bahan Aktif Ekstrak Lengkuas (Alpinia galanga L.Swartz.), Bul. Litro.21(2): 192-205

Moniharapon, P.J., Queljoe, E.D., \& Simbala, H. (2016). Identifikasi fitokimia dan uji antioksidan ekstrak etanol tauge (Phaseolus radiatus L.) jurnal ilmiah farmasiUNSRAT.Vol. 5(4).

Meilina, R., \& Afriana, S. (2019). Efek Antiinflamasi Gel Kacang Hijau Pada Mencit Putih (Mus Musculus). Journal of Healthcare Technology and Medicine Vol. 5 No. 2.

Meilina, R., Suwarso, E., \& Dalimunthe, A. (2018). Relaxation effect of ethanolic extract of averrhoa bilimbi 1. Leaves on ileum smooth muscle contraction of in vitro isolated rat (rattus norvegicus). Asian journal pharmaceutical and clinical reasearch. Vol 11, special issue 1. 